Geograficando, vol. 15, n. ${ }^{\circ}$ 1, e049, mayo-octubre 2019. ISSN 2346-898X

Universidad Nacional de La Plata.

Facultad de Humanidades y Ciencias de la Educación.

Departamento de Geografía

\title{
The evolution of the school population in the Carpathian Mountain Space. Case study: urban and rural environment of Apuseni Mountains (Romania)
} La evolución de la población escolar en el Espacio Montañoso de los Cárpatos. Estudio de caso: entorno urbano y
rural de las Montañas Apuseni (Romania)

Mădălin-Sebastian Lung

Babeș-Bolyai University, Faculty of Geography, Rumania

lungmadalin@yahoo.com

\section{Abstract:}

The purpose of the article is to analyze the evolution of the school population in the Apuseni Mountains in the range 1992-2017. For the implementation of the article we needed statistical data that we took over from the National Institute of Statistics. After they were obtained, they were processed in Microsoft Excel, and then the database was built that was introduced in the ARC Gis 10.3 program. After entering data in geographic information systems, a number of maps were generated on the herd, decreases and population increases during the period mentioned. The school population has been and is influenced by the migratory dynamics of the population. As the young population leaves and does not come back, it remains the elderly population that can no longer reproduce. The few administrative units in which the school population grew was due to the positive evolution of ethnicities.

KEYWORDS: School population, Carpathian Mountain Space, Apuseni Mountains.

\section{RESUMEN:}

El propósito del artículo es analizar la evolución de la población escolar en las montañas Apuseni en el rango 1992-2017. Para la implementación del artículo necesitábamos datos estadísticos que asumiéramos del Instituto Nacional de estadística. Después de que se obtuvieron, se procesaron en Microsoft Excel y, a continuación, se construyó la base de datos que se introdujo en el programa ARC GIS 10.3. Después de introducir datos en sistemas de información geográfica, se generaron varios mapas en el rebaño, disminución y aumento de la población durante el período mencionado. La población escolar ha sido y está influenciada por la dinámica migratoria de la población. A medida que la población joven se va y no regresa, sigue siendo la población anciana que ya no puede reproducirse. Las pocas unidades administrativas en las que creció la población escolar se debieron a la evolución positiva de las etnias.

Palabras Clave: Población escolar, Espacio de la Montaña de los Cárpatos, Montes Apuseni.

\section{INTRODUCTION}

The purpose of this study is to analyze the evolution of the school population in the rural and urban area of the Apuseni Mountains between 1992-2017. We wanted to actually see how much the number of the school population was for each administrative unit and to learn the increases and decreases of the school herds. We have also tried to identify causes that have been the basis for the positive evolution of the school population in the few administrative units.

This is a first study that focuses on studying the school population within these mountains. Basically, we wanted to see if the migratory dynamics, respectively, the risk phenomena that are being carried out in the Apuseni Mountains, induce state of risk on the school population. In the few administrative units where there were increases, they were based on the positive evolution of ethnic communities.

Many research on the school population or school institutions had different approaches.

Secareanu \& Sîrodoev (2017) conducted a study on the development of education and the evolution of the school population in the rural area of Arges County during the post-economic crisis. Verdugo (2018) studied the school population in the USA, making a brief monograph of the school population during the period 1900-2010. It identifies several essential factors that led to the change in the demographic profile of the school population. Factors such as immigration from Europe, domestic migration, fertility growth 
and growth of Baby Boom, the changing status of women and minorities, urban crises, increased social inequality, recession in 2008 and globalization. A team of researchers from the USA and China conducted a comprehensive study on the school climate in the two countries, to identify the differences between the two systems (Bear et al., 2018). Smirnov \& Shihina (2016) focused on the research of the difficulties of schooling indigenous people in the rural areas of Alaska. They recorded that the main problems arise because of the negative social factors such as the high level of poverty among the local population, alcoholism and child abuse. A collective of researchers have drawn up research on ideological polarization and organizational evolution on secular Islamic rivalry in Turkish education institutions (Boone et al., 2017).

Other studies include in an ensemble the school population, respectively relations between pupils and teachers, as well as factors that induce positive and negative states on the functionality of education in certain regions of the world (Buckland, 1958; Hayashi, 1963; Ankrah-Dove, 1982; Ilon, L., Moock, P., 1991; Okano, 2004; Bühler et al., 2013)

\section{STUDY AREA}

The Apuseni Mountains (figure 1) represent an expanded mountain unit on about $10.750 \mathrm{~km} 2$ and is part of the Romanian Carpathians. The northern boundary of the mountains is given by the Barcăului Valley, the eastern boundary of contact with the Transylvanian Depression, in the south the boundary is given by the Mureş Valley, and in the east the limit is one sinuous to the connection with the West Hills. In the central part there is a higher area with altitudes of more than 1.800 meters (Vlădeasa, Bihor and GilăuMuntele Mare) followed by a lower area (Pop, 2000). The process of heightened humanity of the Apuseni Mountains has been carried out over historical times, with continuity and cyclicality in the populating of these mountains. The settlements were placed in depressions, followed by the demographic pressure to spread across the valleys and reach altitudes of more than 1.200-1.300 feet.

\section{FIGURE 1}

The geographical position of the Apuseni Mountains.

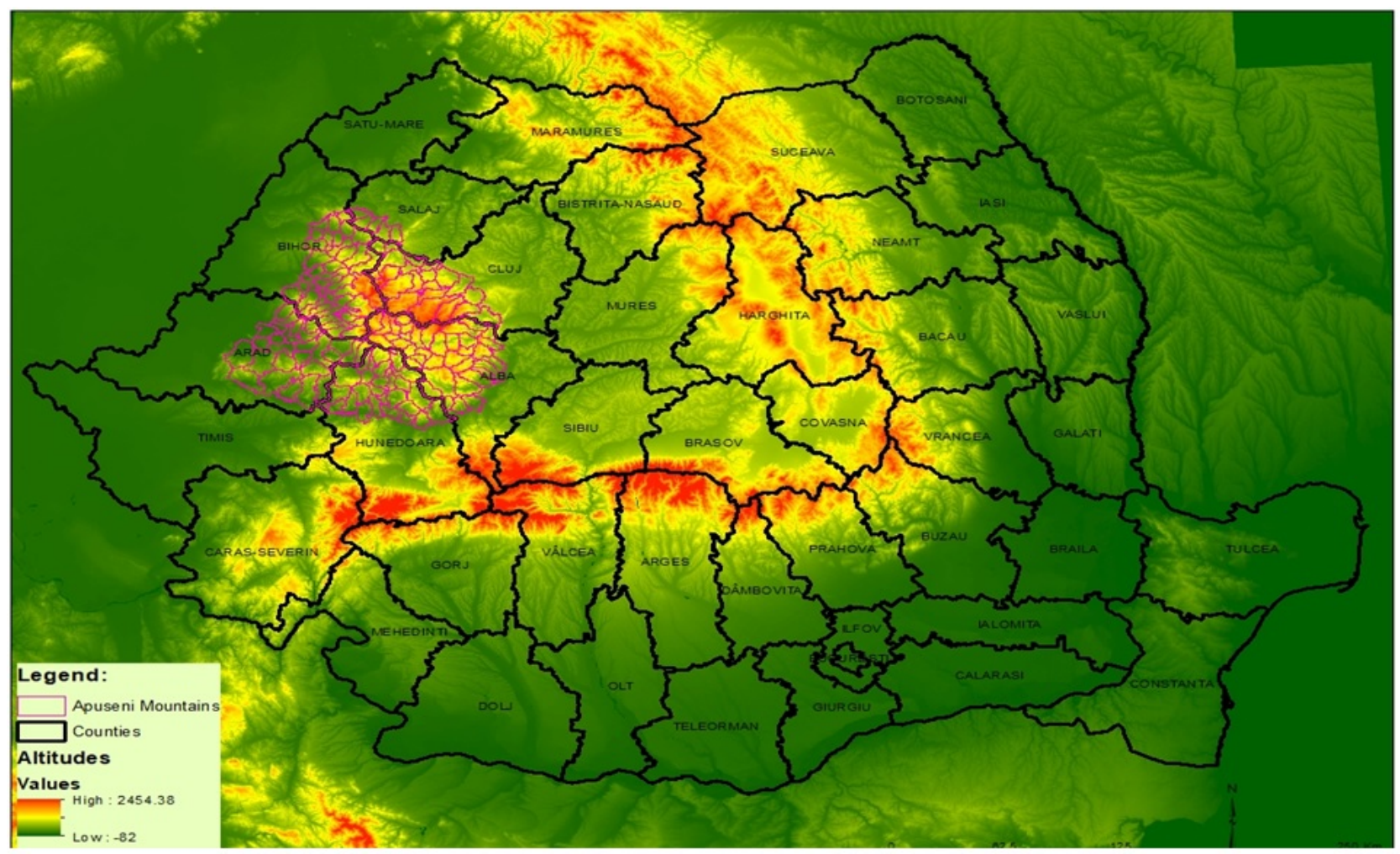




\section{METHODOLOGY}

For the administrative demarcation of the Apuseni Mountains was consulted the existing specialized bibliography (Drăgan, 2011; Surd et al., 2017). Finally, the administrative boundary of the Apuseni Mountains consists of 153 administrative-territorial units. Of the 153, 140 are common (rural area) and 13 are cities (urban space).

Statistical data from the National Institute of Statistics were used to achieve this study. After obtaining the required numerical data, they were introduced and processed in the Microsoft Excel 2013 program. Also, calculations were made on the evolution of the school population in the period 1992-2017. The implementation of tables was based on the analysis of the school population in urban area, given the small number of only 13 cities.

Through geographic information systems, the database was introduced in the ARC Gis 10.3 program, and a series of maps on the distribution of population populations was generated. Several graphics have also been drawn up.

\section{RESULTS AND DISCUSSIONS}

\section{The evolution of the school population in the urban area of the Apuseni Mountains}

The school population in the urban environment of the Apuseni Mountains was in a continuous decrease from 1992 to 2017.

FIGURE 2

The evolution of the school population in the urban area of the Apuseni Mountains.

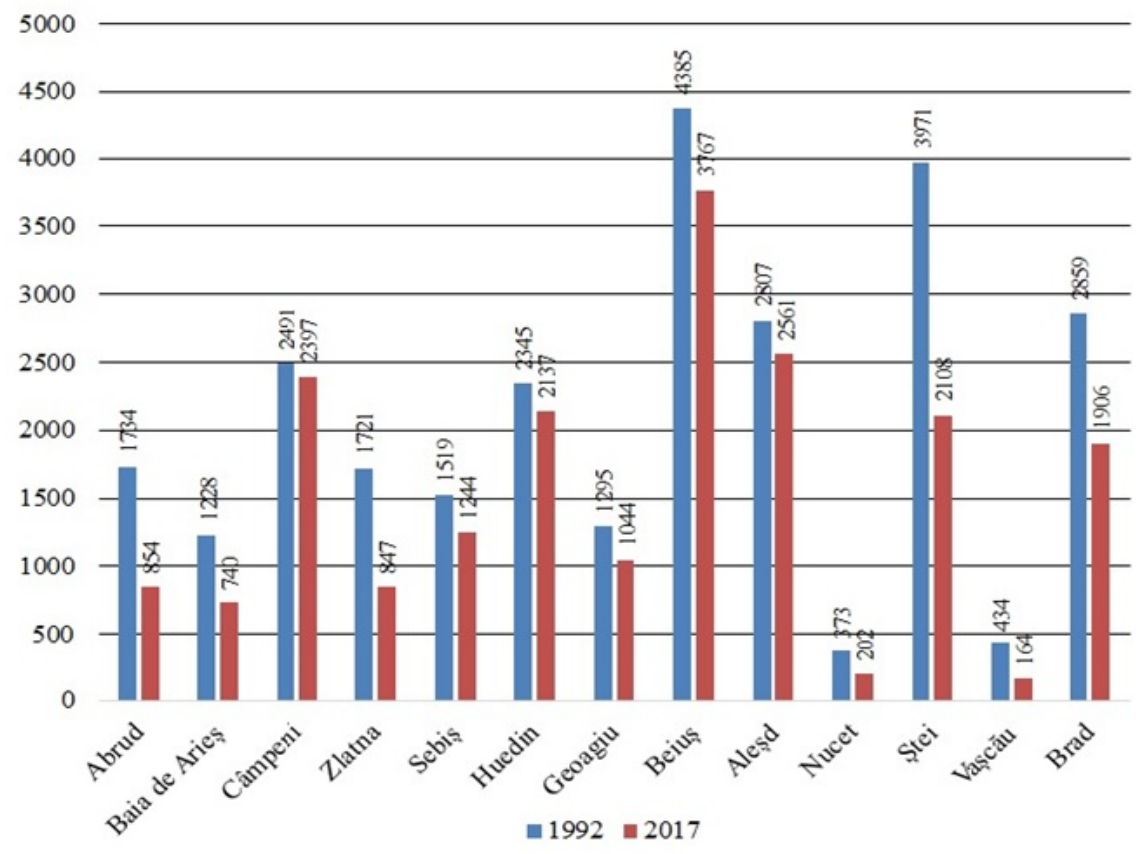


In 1992, the herd of the school population of the 13 cities was 27.162 students. The largest number of pupils was registered in the town of Beiuş in Bihor County, and the opposite pole was the town of Nucet in the same county with only 373 students. Under the percentage aspect, only four cities passed as a total share of more than $10 \%$. The city of Beiuş held 16,1\% of the total pupils, followed by Ştei by $14,6 \%$ and Brad by $10,5 \%$ and Aleșd by $10,3 \%$.

TABLE 1

The school population in the urban area of the Apuseni Mountains in 1992.

\begin{tabular}{|c|c|c|c|}
\hline Nr. Crt. & Cities & $\begin{array}{c}\text { School population in } \\
1992\end{array}$ & \% of the total of 27,162 \\
\hline 1. & Abrud & 1.734 & 6,3 \\
\hline 2. & Baia de Arieș & 1.228 & 4,5 \\
\hline 3. & Câmpeni & 2.491 & 9,1 \\
\hline 4. & Zlatna & 1.721 & 6,3 \\
\hline 5. & Sebiș & 1.519 & 5,5 \\
\hline 6. & Huedin & 2.345 & 8,6 \\
\hline 7. & Geoagiu & 1.295 & 4,7 \\
\hline 8. & Beiuș & 4.385 & 16,1 \\
\hline 9. & Aleșd & 2.807 & 10,3 \\
\hline 10. & Nucet & 373 & 1,3 \\
\hline 11. & Ștei & 3.971 & 14,6 \\
\hline 12. & Vașcău & 434 & 1,6 \\
\hline 13. & Brad & 2.859 & 10,5 \\
\hline
\end{tabular}

Source: data processed after the NIS.

In the year 2017, the situation of the school population in the urban area of the Apuseni Mountains was completely changed. The number of pupils dropped to 13 cities by $-26,4 \%$ compared to 1992 , to 19.971 pupils. Decrease registered in the 25 years was 7.191 pupils. The whole town of Beiuş occupied the first place as having the highest school flock with 3.767 pupils and a share of 18,8 \%. This time, the last place was occupied by the city of in Vaşcău with 164 pupils, and the recorded share was lowest in cities, of only 0,8 $\%$. In 2017, five cities had total weights of over $10 \%$. The following four after Beiuş are: Aleșd by 12,8 \%, Câmpeni by $12,0 \%$, Huedin by $10,7 \%$ and Ştei by $10,5 \%$.

TABLE 2

The school population in the urban area of the Apuseni Mountains in 2017.

\begin{tabular}{|c|c|c|c|}
\hline Nr. Crt. & Cities & $\begin{array}{c}\text { School population in } \\
2017\end{array}$ & \% of the total of 19,971 \\
\hline 1. & Abrud & 854 & 4,2 \\
\hline 2. & Baia de Arieș & 740 & 3,7 \\
\hline 3. & Câmpeni & 2.397 & 12,0 \\
\hline 4. & Zlatna & 847 & 4,2 \\
\hline 5. & Sebiș & 1.244 & 6,2 \\
\hline 6. & Huedin & 2.137 & 10,7 \\
\hline 7. & Geoagiu & 1.295 & 6,4 \\
\hline 8. & Beiuș & 3.767 & 18,8 \\
\hline 9. & Aleșd & 2.561 & 12,8 \\
\hline 10. & Nucet & 202 & 1,0 \\
\hline 11. & Ștei & 2.108 & 10,5 \\
\hline 12. & Vașcău & 164 & 0,8 \\
\hline 13. & Brad & 1.906 & 9,5 \\
\hline
\end{tabular}


In the period 1992-2017, a decrease of the school population in the urban area of the Apuseni Mountains of $26,4 \%$ was recorded. The decreases were very high in the 25 years, for five of the cities, the decreases being over $40 \%$. The largest school dysfunctions were in in Vaşcău, where the number of pupils decreased by $62,2 \%$, being the largest decrease of all cities during the studied period. After in Vaşcău, two other cities followed (Abrud and Zlatna both in Alba County) that had similar decreases, each of 50,7 \%. Not long distance from the two, it was Șteiul with a decrease of $46,9 \%$ and Nucetul by $45,8 \%$. The lowest decreases we considered to be those below $10 \%$ in which three urban centers fall. The school population of Huedinului (Cluj County) decreased by 8,8 \%, the Aleșdului (Bihor County) with 8,7\% and the city of Câmpeni (Alba County) by 3,7 \%. Most of these administrative units had industrial function during the socialist period. After the Revolution of 1989 and the transition to capitalism, they started restructuring in the industry, which led to the redundancy of the workers. After loss of employment, the young workforce migrated to other cities or outside the country. The departure of the young population has attracted the decrease of the school population that can be seen in table 3 .

TABLE 3

Decrease of the school population in the urban area of the Apuseni Mountains in 1992-2017.

\begin{tabular}{|c|c|c|c|c|}
\hline Nr. Crt. & Cities & $\begin{array}{c}\text { School population } \\
\text { in 1992 }\end{array}$ & $\begin{array}{c}\text { School population } \\
\text { in 2017 }\end{array}$ & \% Decrease \\
\hline 1. & Abrud & 1.734 & 854 & $-50,7$ \\
\hline 2. & Baia de Arieș & 1.228 & 740 & $-39,7$ \\
\hline 3. & Câmpeni & 2.491 & 2.397 & $-3,7$ \\
\hline 4. & Zlatna & 1.721 & 847 & $-50,7$ \\
\hline 5. & Sebiș & 1.519 & 1.244 & $-18,1$ \\
\hline 6. & Huedin & 2.345 & 2.137 & $-8,8$ \\
\hline 7. & Geoagiu & 1.295 & 1.044 & $-19,3$ \\
\hline 8. & Beiuș & 4.385 & 3.767 & $-14,0$ \\
\hline 9. & Aleșd & 2.807 & 2.561 & $-8,7$ \\
\hline 10. & Nucet & 373 & 202 & $-45,8$ \\
\hline 11. & Ștei & 3.971 & 2.108 & $-46,9$ \\
\hline 12. & Vașcău & 434 & 164 & $-62,2$ \\
\hline 13. & Brad & 2.859 & 1.906 & $-33,3$ \\
\hline Total & & 27.162 & 19.971 & $-26,4$ \\
\hline
\end{tabular}

Source: data processed after the NIS.

\section{The evolution of the school population in the rural area of the Apuseni Mountains}

Due to the fact that the Apuseni Mountains largely comprise the rural area, the number of rural pupils is somewhat higher than the pupils in the urban environment. The spatial distribution of the number of school population for each common is represented in figure 3. In the year 1992, in the rural mountains, there was a school population of 48.851 students.

The largest number of pupils was registered in the Apuseni Bihorului, with 15.175 pupils. The largest number was recorded in the municipality of Dobreşti (861). The following two commoners after Dobreşti, also had high herds of the school population. The municipality of Şuncuiuş had 792 pupils, and the Bratca commune had 787. We notice the very small difference between the two administrative units, of only 5 students. The smallest number of pupils was 188, registered in the Pocola commune. 
The Apuseni Albei concentrated the second herd of the school population in 1992. The number of pupils was 9.946, with the maximum in the commune of Ighiu, where they taught 932 children. Of the 33 communes that form the Apuseni Albei, four had less than 100 students each. Thus the municipality of Ocoliş had 97, the commune of Râmeț (68), the commune Ponor (54) and the smallest school herd was 52 students, in the commune of Ceru-Băcăinți.

In the Apuseni Clujului, they learned in 1992, a number of 7.280 students. The Gilău municipality had the highest number of pupils, 1.260, being the second herd of the school population in the entire territory of the Apuseni Mountains. The large number of the school population is given by the total population of the commune, which according to the National Institute of Statistics was 7.966 inhabitants. At the opposite pole was the commune of Sâncraiu, where they learned 161 children. The lower school population of this municipality can be justified by the small number of inhabitants, of only 2.053. Also, in addition to the small number of the population, this unit has an ethnic specificity. According to the data of the institute mentioned above $78-80 \%$ of the population of the commune is Hungarian ethnicity, which have established a different policy of organizing the family.

In the Apuseni Aradului, the school population in the year 1992 was 7.240 children. The Gurahont commune was placed in the first position with 971 pupils, and the minimum values fell below 100 pupils in two administrative units. The two minimums in the Apuseni Aradului are: Silindia commune (88 pupils) and commune Igneşti ( 85 pupils). The reduced school population is given by the total number of inhabitants of the two municipalities, which has been reduced, Silindia having 1.047 inhabitants, and Igneşti 825 inhabitants.

The Apuseni Hunedoarei had in 1992, the second smallest flock of the school population in the Apuseni Mountains. In their space they were learning 7.018 children. The largest number of pupils registered at the level of the Apuseni Hunedoarei, but also at the level of the entire territory of the Apuseni Mountains, was 1.434 , in the commune of Criscior. At a total population of 4.488 inhabitants, it is apparent that no less than $32 \%$ of the population of the commune was a school population. We observe the young character of this commune. Four communes were placed on the last seats, having each under 100 pupils (Tomeşti 99 pupils, Balşa 49 pupils, Burjuc 46 pupils, Bulzeștii de Sus 7 pupils). The Bulzeștii de Sus municipality has recorded the lowest number of the school population in the Apuseni Mountains. This acute phenomenon is explained by the small number of the total population, which in 1992 had only 580 inhabitants.

In the last place as a number of pupils were the Apuseni Sălajului, where they were learning 2.192 children. It is a fairly high herd because this part of the Apuseni Mountains comprises only five administrative units. In all municipalities, the school population had high values without being able to say that there is a clear minimum (Sâg 562, Valcău de Jos 518, Plopiş 393, Halmăşd 377, Cizer 342). 
FIGURE 3

Distribution of the school population in the rural area of the Apuseni Mountains in 1992.

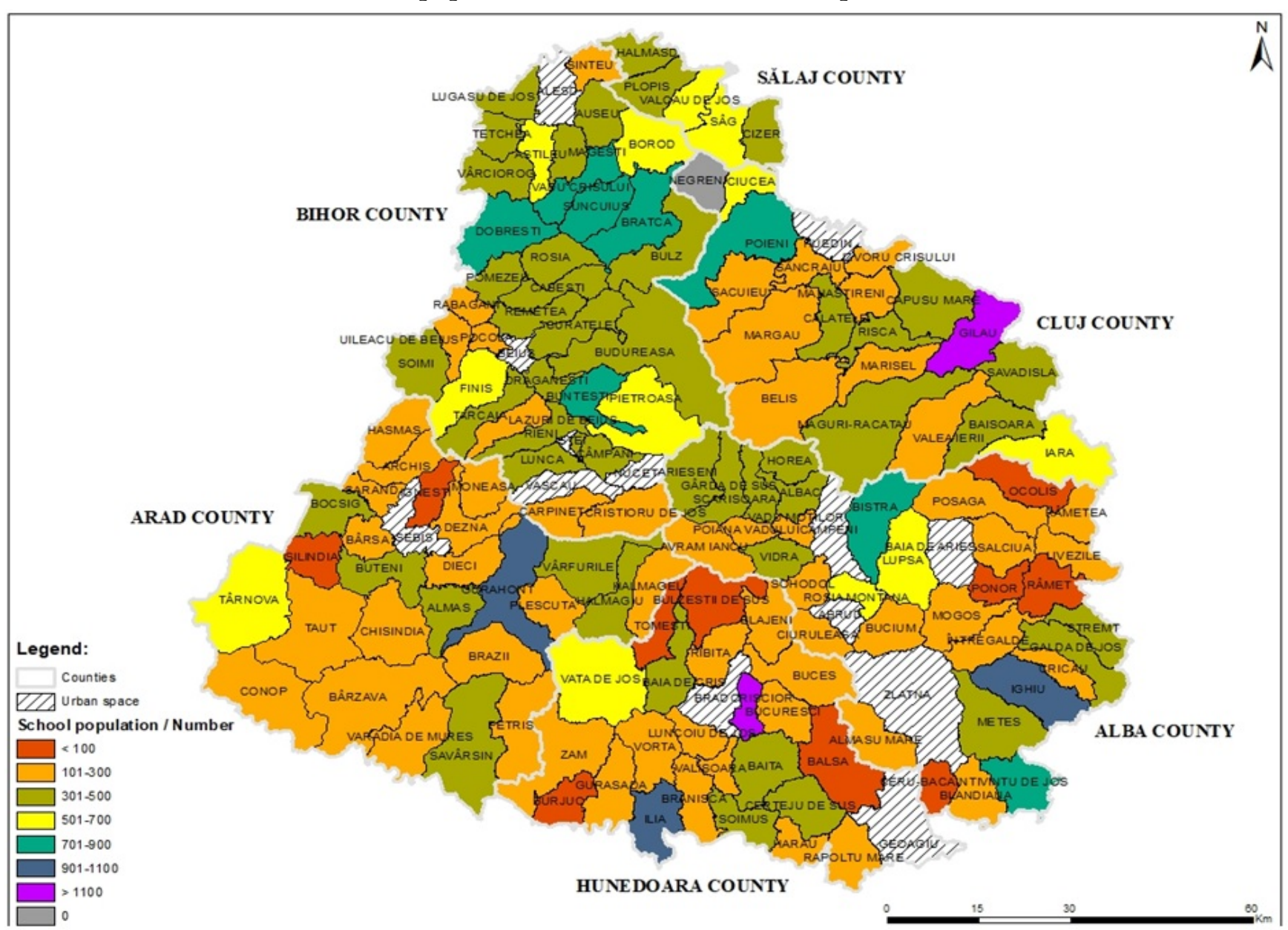

Source: data processed after the NIS (value 0 is given for the Negreni municipality that did not exist in 1992, being established by referendum in 2002 and was not counted for 2017).

In figure 4 we can see the distribution of the weightings on the school population of 1992 for each group forming the Apuseni Mountains. The largest share of the Apuseni Bihorului by $31 \%$, followed by the Apuseni Albei by $20 \%$, respectively to the Apuseni Aradului and Clujului each with $15 \%$. The smallest share had the Apuseni Hunedoarei by $14 \%$ and the Apuseni Sălajului by $5 \%$. 
FIGURE 4

Distribution of weights on the school population in the rural area of the Apuseni Mountains in 1992.

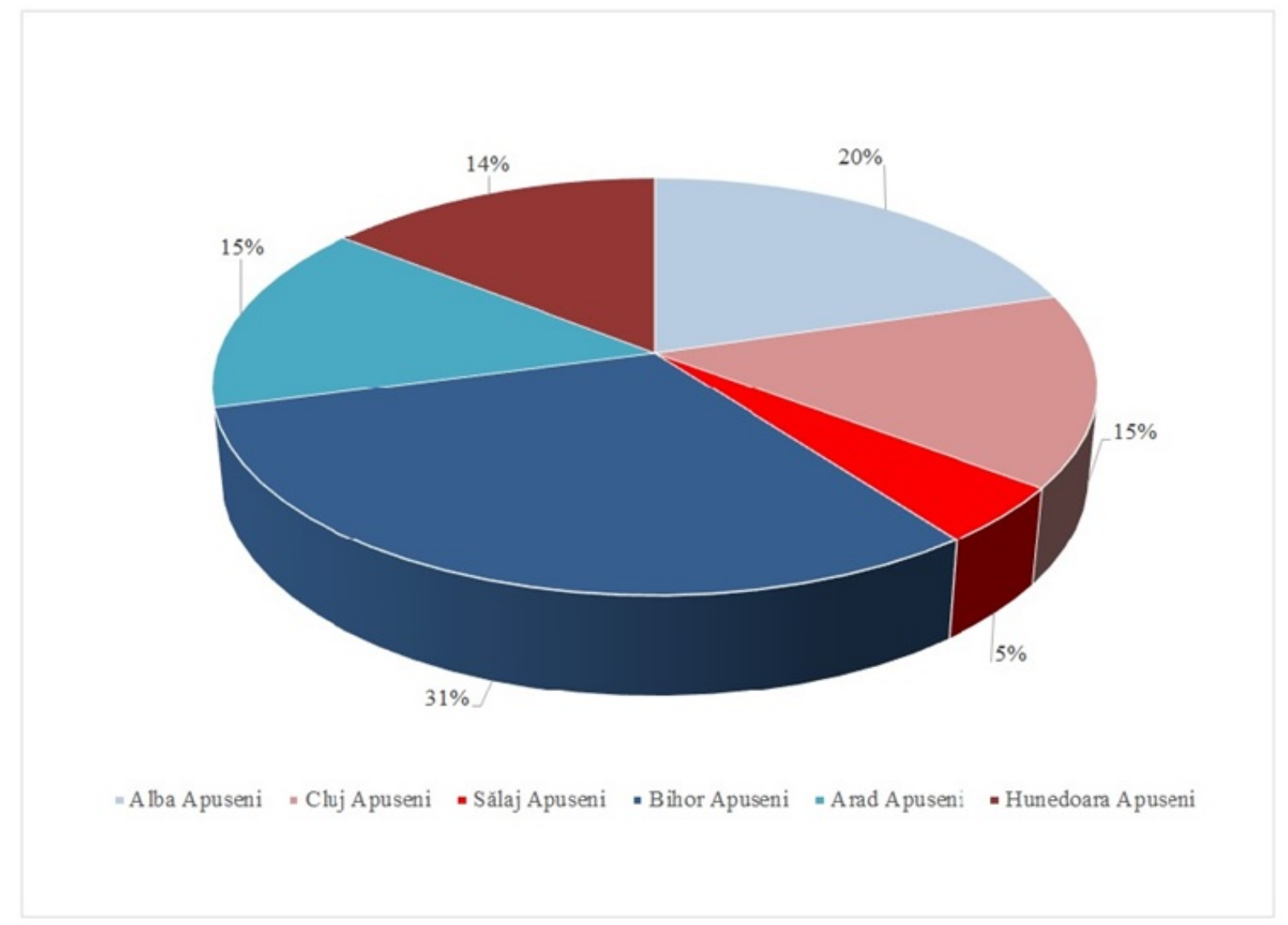

Source: data processed after the NIS.

After 25 years, the situation of the school population in the rural area of the Apuseni Mountains was completely changed. The number of school population decreased between $1992-2017$ and 17.772 pupils, reaching 48.851 in 1992, to 31.079 in 2017 . Of the 140 communes that form the rural environment of the Apuseni Mountains, in only 10 there were registered increases in the school population.

Five communes belong to the Apuseni Bihorului (Vadu Crişului, Țețchea, Dobreşti, Lugaşu de Jos, Şuncuiuş). Together they had an increase of 455 pupils, compared to the year 1992, and the distribution of flocks is unhomogeneous: Vadu Crișului 193, Dobrești 155, Țețchea 57, Șuncuiuș 28, Lugașu de Jos 22. In Dobreşti this increase in the school population was due to ethnic Gypsies. In 1992, according to the National Institute of Statistics, the commune lived 557 gypsies and in 2017 their number reached 786. Similarly it is the case of the Şuncuiuş commune where ethnic Gypsiess increased from 104 in 1992, to 252 in the year 2017. In Lugaşu de Jos the situation is more pronounced because the demographic contribution has increased in 25 years among two ethnicities. The number of Hungarians grew in these years from 691 to 1.024, being an increase of $48 \%$. The gypsy community grew from 527 in 1992, to 689 in 2017. This increase is $30 \%$.

The Apuseni Aradului registered increases in four other: Săvârşin 133, Târnova 41, Silindia 10, Bârsa 6. The school population increased to four administrative units with 190 pupils. In the municipality of Târnova prospered during the 25 years, ethnicity Gypsy and ethnicity Ukrainian. Ethnic Gypsiess had 1992, 96 citizens, and 25 years later their number was 117 , registering an increase of $21 \%$. The population of Ukrainians origin has prospered very much during this time period. Thus, in 1992 there were 70 Ukrainians, 
and in 2017 their flock reached 557 people. The Apuseni Albei had only one common (Albac) in which the school population was growing by 89 pupils.

Compared to 1992, we can see from figure 4 that administrative units that have less than 100 pupils have increased their numbers considerably. In 25 years, the number of municipalities in which the school population fell below 100 pupils, reached from 10 in 1992 to 39 in 2017. Their largest number is in the Apuseni Albei and Hunedoarei. We can also notice the lack of maximum values that existed in 1992. In 2017, the values over 1.100 are missing, the highest being between 901-1.100, in Gilău, Dobreşti and Vadu Crişului. We note for the year 2017, increasing the number of municipalities that had a school population between 101-300. Basically, it is a decrease in the number of municipalities that in 1992 had values ranging from 301-500, and in 2017 the school population fell so much that they passed between 101-300 and < 100 . If in 1992, there were 46 administrative units between 301-500, in 2017 their number reached 14. Growing compared to 1992, there were communes with the school population between 101-300, from 58 to 1992, to 72 in 2017.

\section{FIGURE 5}

Distribution of the school population in the rural area of the Apuseni Mountains in 2017.

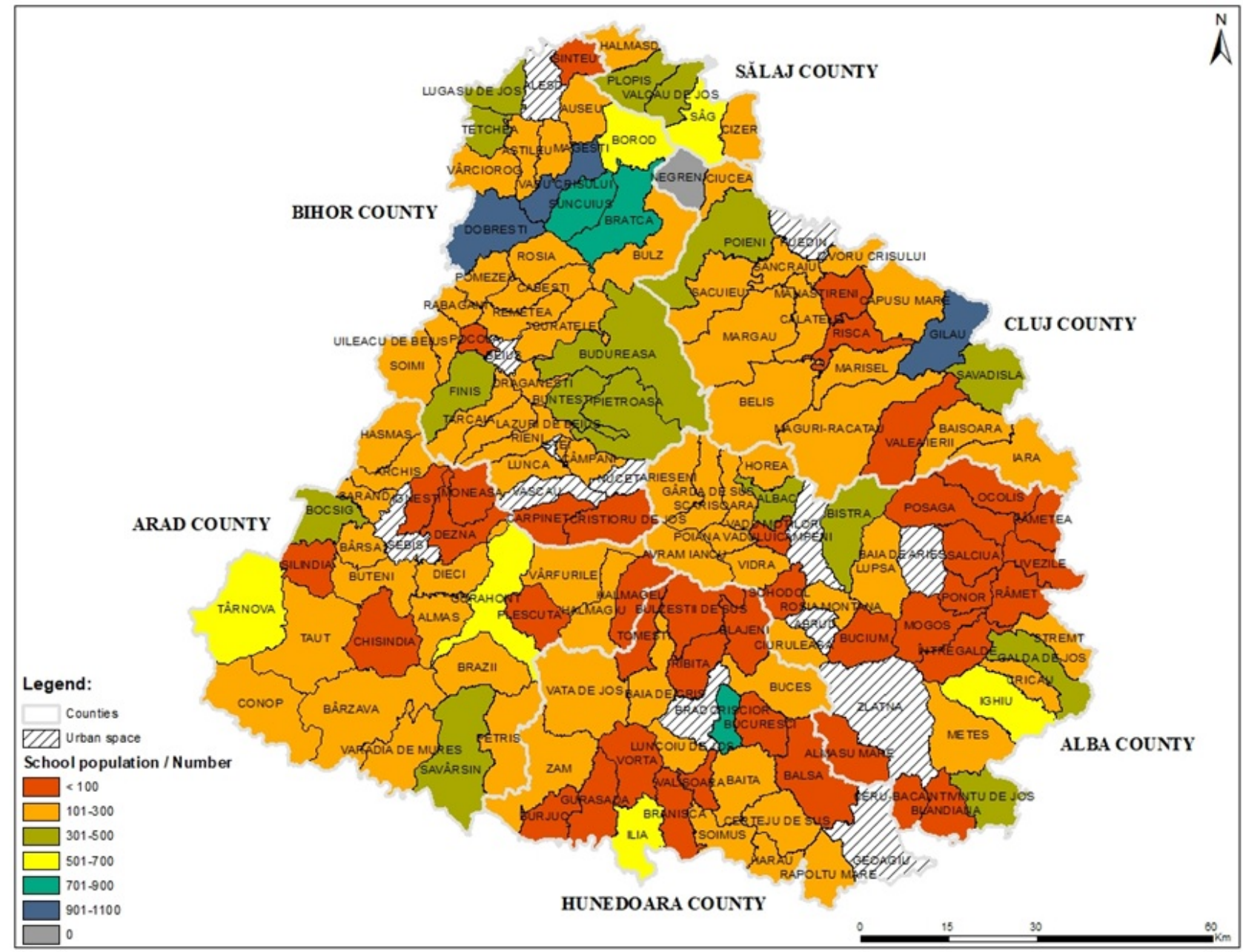

Source: data processed after the NIS (value 0 is given for the Negreni municipality that did not exist in 1992, being established by referendum in 2002 and was not counted for 2017).

In figure 6 we made a cartographic representation of the increases and decreases of the school population in 1992-2017. Decreases dominates clearly, with very high values being recorded. No less than 13 municipalities had decrease of the school population over $70 \%$, but most of the decreases are between $(-30.1)-(-70) \%$. 
These values are distributed in the entire area of the Apuseni Mountains, both in the high mountain areas and in the marginal areas at the contact of the mountain area with the hill area, of depression.

The highest positive values were recorded in four municipalities: Săvârșin 38,2 \%, Albac 29,2 \%, Dobreşti $18 \%$ and Vadu Crişului 27,1 \%. In these, the growths of the school population have passed 15,1\%.

In three other administrative units the increases were between 0-5\% (Lugaşu de Jos 4,7 \%, Şuncuiuş 3,5 \%, Bârsa 3 \%). In Târnova the school population increased by 6,3 \%, in Țețchea by 14,7 \% and in Silindia with $12,5 \%$.

We note that out of the 140 communes only 10 had increases in the school population from 1992 to 2017. These demographic dysfunctions exist because of the risk demographic phenomena that are being conducted since 1990. The dysfunctions were sharpened with the passage of time, reaching almost entirely the Apuseni Mountains. One of the great problems facing the Apuseni Mountains can be seen in figure 7 where the migratory balance rates are represented in the year 2017. No solutions have yet been found to stop the population migration, but the serious problem is that it migrates the young population. Young people leave the area of the Apuseni Mountains looking for a better place to live, where to find jobs for educational purposes and more. Basically, the migration of young people is a risk phenomenon that leads to the emergence of another risk phenomenon, which is demographic ageing. In their wake, it remains the elderly population that still carries out subsistence agriculture. A new phenomenon of risk, depopulation, is emerging from the system of the elderly population. In the Apuseni Mountains there is the chain of these three risk demographic phenomena that induce major demographic malfunctions.

\section{FIGURE 6}

Distribution of increases and decreases of the school population in the rural area of the Apuseni Mountains from 1992-2017.

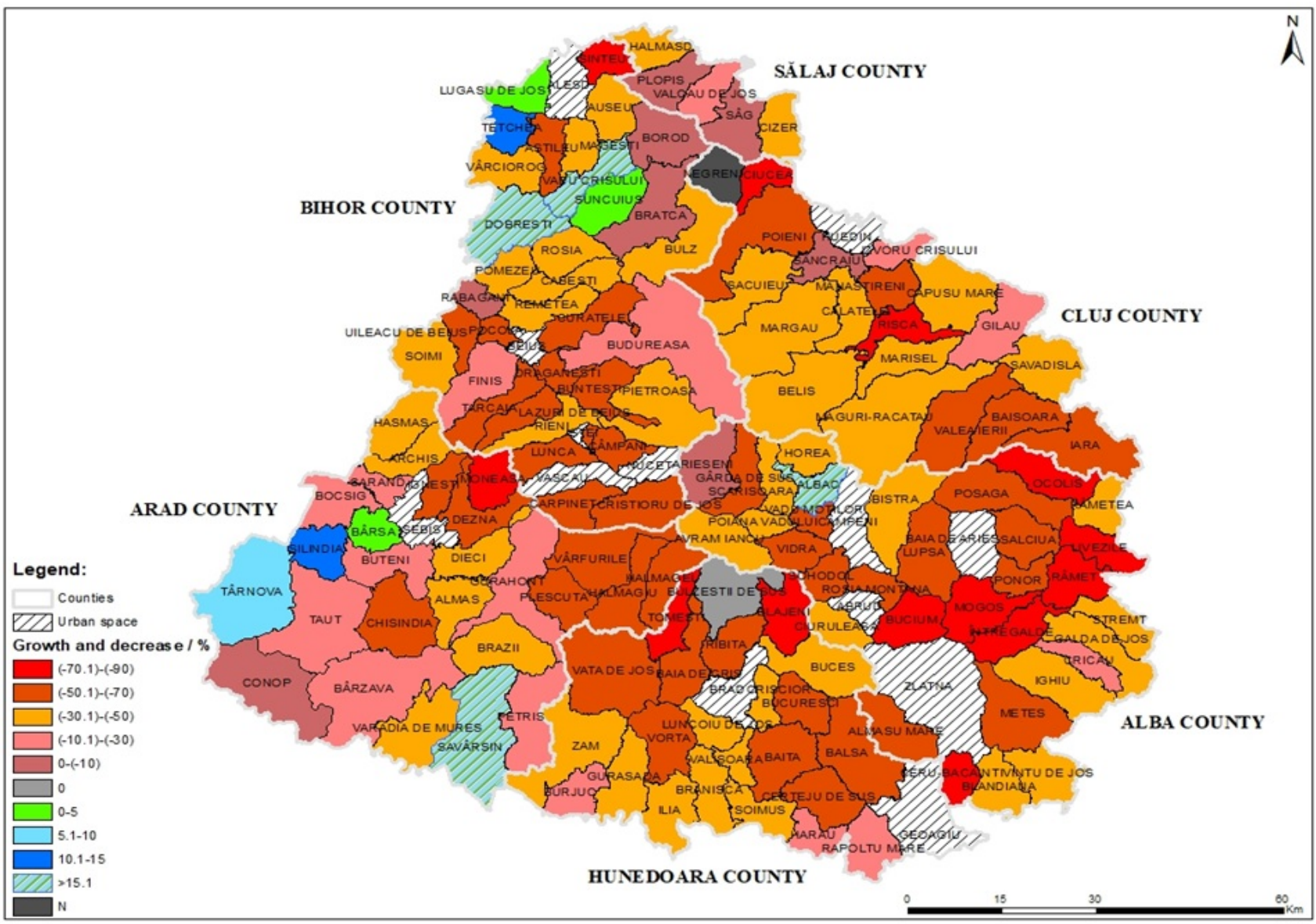

Source: data processed after the NIS (the N value is given for the common Negreni that did not exist in 1992, being established by referendum in 2002 and was not counted for 2017). 
FIGURE 7

Distribution of migratory balance rates in the rural area of the Apuseni Mountains in 2017.

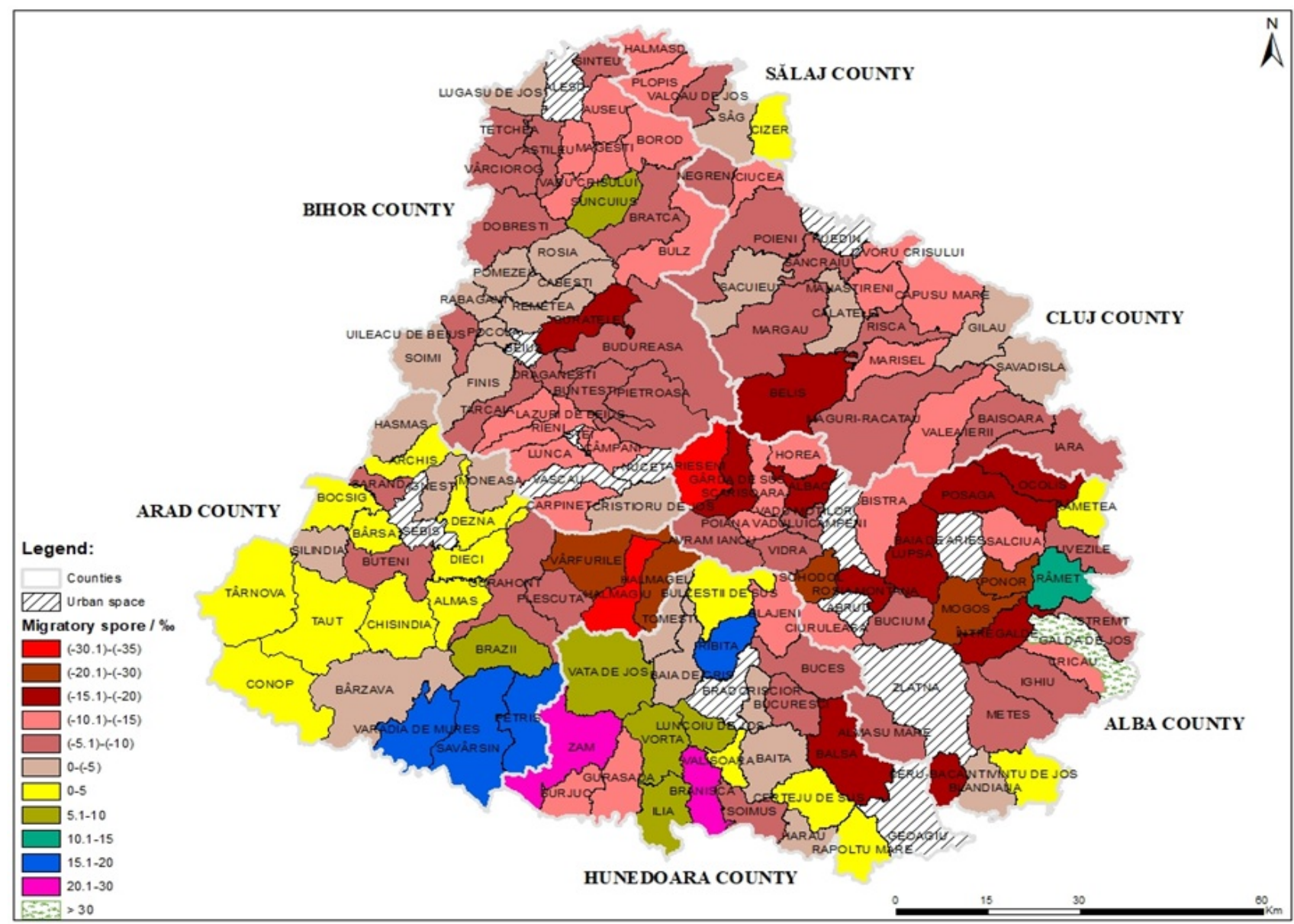

Source: data processed after the NIS.

\section{CONCLUSIONS}

Finally, we learned that the dynamics of the school population are in a continuous decrease in both rural and urban areas. There are only a few cases where evolution has been ascending, and this growth has had ethnic causes. Where there were increases, they were the cause of the positive evolution of ethnic communities. The ethnicities that helped establish increases among the school population were Hungarian, Ukrainians and Gypsy.

In parallel with the ethnic factor, migratory dynamics is another cause that led to a decrease in the school herd in the time interval 1992-2017. Practically, migration dynamics has brought significant consequences to the decrease in the number of pupils. Of the 153 administrative units more than 100 had in 2017 the negative migratory balance rate. The departure of the young population is a phenomenon that has been exerted for 25 years. In these years, due to the departure of young people, other demographics of risk (demographic ageing, depopulation) have emerged in close connection to the dynamic component of the Apuseni Mountains.

\section{REFERENCES}

Ankrah-Dove, L. Int Rev Educ (1982) 28: 3. https://doi.org/10.1007/BF00597756 
Bear, G-G., Yang, C., Chen, D., He, X., Xie, Jia-Shu., H-X. (2018). Differences in school climate and student engagement in China and the United States. School Psychology Quarterly, Vol 33(2), Jun, 2018. pp. 323-335. Recuperado de: https://eric.ed.gov/?id=EJ1181712

Boone, C., Divarcı Çakmaklı, A., van Witteloostuijn, A. (2017). Ideological Polarization and Organizational Form Evolution: A Study of Islamic-Secular Rivalry and High Schools in Turkey, 1971-1998. Social Forces, vol. 96, Issue 4, pp. 1593-1624. Recuperado de: https://muse.jhu.edu/article/695683/pdf

Bühler, M.D.,Curth, M.T., \& Garibaldi, L.A., (2013). Demography and socioeconomic vulnerability influence fire occurrence in Bariloche (Argentina). Landscape and Urban Planning, 110 (2013) pp. 64-73. Recuperado de: https://ac.els-cdn.com/S0169204612002873/1-s2.0-S0169204612002873-main.pdf?_tid=2597c308-1e8 5-43e0-831c-a7a3958b33ec\&acdnat=1545294169_30d8566a0900937fc234cbc4d31cb17c

Buckland, R.V. (1958). Rural School Improvement Project: 1953-1957 Report. Berea, Kentucky: Berea College, ED 15801.

Drăgan, M. (2011). Reziliența sistemului regional Munții Apuseni [Resilience of the Apuseni Mountains regional system], (Tesis inédita de maestría o doctorado). Babeş-Bolyai University. Faculty of Geography. Cluj-Napoca. Romania.

Hayashi, T. Int Rev Educ (1963) 9: 241. https://doi.org/10.1007/BF01417005

Ilon, L. \& Moock, P. Int Rev Educ (1991) 37: 429. https://doi.org/10.1007/BF00597620

Okano, K.H. International Review of Education (2004) 50: 119. https://doi.org/10.1023/B:REVI.0000041909.02 121.91

Pop, G. (2000). Carpații și Subcarpaţii României [Carpathians and Sub-Carpathians of Romania]. Editura Presa Universitară Clujeană. Cluj-Napoca, Romania.

Secăreanu, G., Sîrodoev, I. (2017). The development of education in the rural areas in the post economic crisis period. Case Study: Argeş county, Romania. Forum Geografic. vol. 16 Issue 2, pp. 144-151. Recuperado de: http://foru mgeografic.ro/wp-content/uploads/2017/2/Sirodoev.pdf

Smirnov, O., Shihina, N. (2016). The evolution of the institutional forms of the educational process of the indigenous population in rural schools: the case of Alaska. Krymskij Naucnyj Vestnik, Vol 2, Iss 4 (10), pp. 131-139. Recuperado de: http://krvestnik.ru/pub/2016/08/11-Smirnov-Shihina.pdf

Surd, V., Constantin, V., ... \& Nicula, A. S. (2017). Aşezările din Munții Apuseni [The settlements in the Apuseni Mountains], Editura Presa Universitară Clujeană, Cluj-Napoca.

Verdugo, R. (2018). American Education and the Demography of the US Student Population, 1880 - 2014, Applied Demography Series, Vol. 10, Cham, Switzerland. Recuperado de: https://www.springer.com/gp/book/978331 9894225

National Institute Of Statistics, http://statistici.insse.ro:8077/tempo-online/\#/pages/tables/insse-table, [consulta: 13-14 de diciembre de 2018]. 